\title{
Note
}

\section{Conservation Through Cooperation: The Collaborative Planning Process for Utility Conservation and Load Management}

\section{Evan van Hook}

The Collaborative Planning Process (CPP) is an experimental administrative procedure that applies the principles of alternative dispute resolution (ADR) ${ }^{1}$ to the complex problem of utility conservation and load management (C\&LM). Despite its potential advantages, the CPP has been criticized as politically illegitimate and too costly. In this Note I propose an organizing statute for the CPP that addresses these concerns.

\section{INTRODUCTION}

Today, many disputes that were traditionally settled in adversarial proceedings are being resolved through ADR procedures. ${ }^{2}$ In many ADR procedures, rather than delegate decisionmaking authority to a third party, the disputants negotiate results and are bound only by agreements to which they consent. ${ }^{3}$

I. ADR refers to a broad variety of procedures designed to allow parties to resolve disputes outside of traditional litigation fora, to reduce the cost of conventional litigation, and to prevent disputes that might otherwise become the subject of litigation. Jethro K. Lieberman \& James F. Henry, Lessons From the Alternative Dispute Resolution Movement, 53 U. CHI. L. REV. 424, 425-26 (1986).

2. See, e.g., Owen M. Fiss, Against Settlement, 93 YALE L.J. 1073 (1984).

3. Daniel J. Fiorino, Regulatory Negotiation as a Policy Process, 48 PUB. ADMN. REV. 764, 768 (1988). 
The use of ADR has been particularly widespread in the resolution of disputes over environmental matters. ${ }^{4}$ Environmental disputes are appropriate for ADR because they often place in opposition two profoundly valid human objectives: our desire to use, and our desire to preserve, the resources of our natural world. ${ }^{5}$ The validity of both objectives makes us sympathetic to resolving environmental disputes in fora that reach an accommodation or compromise between them, rather than choosing one over the other. ${ }^{6}$ However, the potentially substantial impact of environmental dispute resolution imposes a special responsibility to ensure that all affected interests are represented, ${ }^{7}$ and that the public interest limits the scope of negotiated settlements.

The proposed use of ADR to settle environmental disputes, therefore, confronts a tension between society's desire to accommodate conflicting policy goals, and the recognition that apparent consensus sometimes masks a failure to account for all affected interests. ADR processes for resolving environmental disputes must be structured to take account of this tension.

This Note examines one such ADR process, the CPP. The CPP is used to resolve disputes between utility companies, which often seek to satisfy growing energy demand by expanding energy production capacity, and conservationists, who prefer to reduce energy demand or to increase the efficiency of energy use. The CPP was developed through contractual agreements between the participants, rather than through official guidance. This Note argues that, while the CPP has the potential to be a superior method for planning C\&LM programs, an organizing statute to direct and constrain the CPP would ensure its procedural integrity and increase its efficiency. The Note is based, in part, on information obtained from interviews that the author conducted with CPP participants throughout New England. Part I discusses the C\&LM problems

4. See, e.g., Bryan M. Johnston \& Paul J. Krupin, The 1989 Pacific Northwest Timber Compromise: An Environmental Dispute Resolution Case Study of a Successful Battle That May Have Lost the War, 27 WILLAMETTE L. REV. 613, 623-24 (1991) (describing increasing use of mediation, negotiation, and facilitation to resolve environmental disputes); Melanie J. Rowland, Bargaining for Life: Protecting Biodiversity Through Mediated Agreements, 22 ENVTL. L. 503, 503 (1992) (discussing growing interest in using mediation and negotiation to resolve environmental disputes); Patricia M. Wald, Negotiation of Environmental Disputes: A New Role for the Courts?, 10 CoLUM. J. ENVTL. L. 1, 3 (1985); see also Eberhard Bohne, Recent Trends in Informal Environmental Confict Resolution, in KONFLIKTBEWAELTIGUNG DURCH VERHANGUNGEN 217 (Wolfgang Hoffman-Riem \& Eberhard Abmann eds., 1990) (describing use of informal agreements to resolve environmental disputes in Germany).

5. See Rowland, supra note 4, at 518-19. A recent example is the dispute over the protection of the spotted owl in the American Northwest. This dispute was often described as a conflict between two mutually exclusive goals, protecting jobs by exploiting the forest resources and protecting an endangered species by preserving those same resources. See Headwaters, Inc. v. Bureau of Land Management, 19 Envtl. L. Rep. (Envtl. L. Inst.) 21,159, 21,161 (D. Or. 1989) (characterizing media coverage of spotted awl controversy as "JOBS versus OWLS").

6. See, e.g., Rowland, supra note 4, at 504 (noting potential for shared knowledge and innovative solutions).

7. See, e.g., Wald, supra note 4, at 19-22 (discussing need for appellate courts to scrutinize negotiated environmental rules because all interests might not have been represented at negotiations). 
that the CPP was designed to address. Part II explains how the CPP works. ${ }^{8}$ Part III discuses the strengths and weaknesses of the CPP, and suggests specific provisions for its organizing statute.

\section{The Problem That The CPP SeEks to AddRess}

America wants its utilities to conserve energy. There are multiple expressions in both state ${ }^{9}$ and federal ${ }^{10}$ law of the principle that a kilowatt saved is better than a kilowatt burned. This notion has even begun to shape our

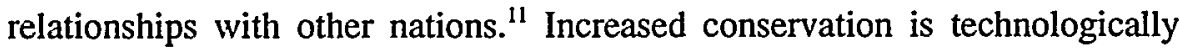
feasible because significant demand-side resources $^{12}$ are available to American utilities. ${ }^{13}$ Switching to efficient technologies could cut our energy use by up to $75 \%$ without a significant change in either our lifestyle or GNP growth. ${ }^{14}$

Conservation is preferable to capacity expansion for several reasons. The consumer has no preference between a kilowatt obtained through conservation

8. Each negotiation group, or "collaborative," using the CPP has a unique, contractually-based format. By lnoking at examples of existing collaboratives, however, we get a sense of how they operate.

9. See, e.g., CAL. PUB. Res. CODE $\S 25008$ (West 1986 \& Supp. 1992) ("It is . . the policy of the state and the intent of the Legislature to promote all feasible means of energy conservation ....."); CONN. GEN. STAT. \$ 16a-35K (1988) ("IT]he general assembly declares that it is the policy of the state of Connecticut to . . . conserve energy resources by avoiding unnecessary and wasteful consumption ....."); GA. CODE ANN. \$ 46-4A-2 (1992) ("The General Assembly finds that the rising cost and uncertain supply of energy resources require an active program of energy conservation assistance . . .."); ME. REV. STAT. ANN. tit. 35-A, $\$ 3191$ (Supp. 1991) ("When the available altematives [for meeting energy capacity requirements] are otherwise equivalent, the commission shall give preference first to conservation and demand management . . ."); MINN. STAT. ANN. § 216C.11 (West 1991) (creating energy conservation information center).

10. See, c.g., 16 U.S.C. $\$ 2601$ (1988) ("The Congress finds that the protection of the public health, safety, and welfare, the preservation of national security, and the proper exercise of congressional authority under the Constitution to regulate interstate commerce require ... a program providing for increased conservation of electric energy [and] increased efficiency in the use of facilities and resources by electric utilities"); 42 U.S.C. $\$ \$ \$ 211-8229$ (1988) (National Energy Conservation Policy, Utility Program); 10 U.S.C.A. $\$ 2865($ b)(3)(A) (West Supp. 1992) (requiring Secretary of Army to encourage military to participate in utility energy conservation programs).

11. See, e.g., Sam H. Verhovek, Cuomo, Citing Economic Issues, Cancels Quebec Power Contract, N.Y. TMIES, March 28, 1992, at 1 ("The Govemor said that New York did not need the power and that it would be cheaper to rely on energy conservation ....").

12. Demand-side resources come from currently under-utilized opportunities to increase the efficiency of energy service delivery. These opportunities become resources when programs are developed that allow utilities to rely on them to an extent comparable to other energy sources. See 2 NATIONAL AsS'N OF

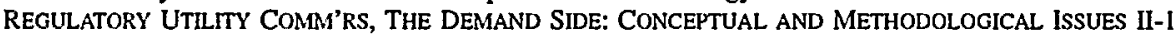
(1988) [hereinafter DEMAND SIDE].

13. The most common way for utilities to access these resources is through direct investment in promoting efficient end-use products. See, e.g., Puget Power Launches "Operation Conservation," Bus. Wire, June 17, 1991, available in LEXIS, Nexis Library, BWIRE file (reporting how Puget Power obtained demand-side resources by supplying residential weatherization, high-efficiency shower heads, faucet aerators, compact fluorescent lights, and appliance rebates to residential customers); Kraft to Get $\$ 2.6$ Million Rebate from Boston Ed for Conservation. INDUS. ENERGY BULL., April 27, 1990, at I (noting that Boston Edison agreed to give rebates to Kraft for accelerated replacement of freon/ammonia refrigeration with ammonia systems, installation of high-efficiency motors and better air-flow equipment, replacement of electric defrost units with hot ammonia system, and installation of energy-efficient lighting and ballasts).

14. Amold P. Fickett et al., Efficient Use of Electricity, SCI. AM., Sept. 1990, at 65, 66. 
and one generated through capacity expansion. ${ }^{15}$ Capacity expansion, however, increases pollution, ${ }^{16}$ diminishes the recreational value of our public lands, ${ }^{17}$ increases our dependence on foreign oil, ${ }^{18}$ and does less for economic development than investment in conservation. ${ }^{19}$

Despite the advantages of demand-side resources, economic and behavioral barriers prevent both consumers and utilities from pursuing conservation aggressively. Discovering appropriate conservation measures imposes high information costs on consumers. ${ }^{20}$ Also, because of "split economic incentives," energy customers require recoupment of costs in as short as one month before making investments in energy efficiency. ${ }^{21}$

Utilities resist conservation because, under traditional rate setting procedures, it has an adverse effect on earnings. ${ }^{22}$ Utility directors may also be afraid to experiment in ways that might result in power shortages, ${ }^{23}$ or

15. See Ralph C. Cavanagh, Least-Cost Planning Imperatives for Electric Utilities and Their Regulators, 10 HARV. ENVTL. L. REV. 299, 315 (1986).

16. Electric utilities produce $70 \%$ of the sulphur dioxide and $33 \%$ of the nitric oxide emissions in America, both of which are thought to be linked to acid rain; $20 \%$ of the gases linked to the greenhouse effect; and 50\% of the nation's nuclear waste. DAVID MOSKOVITZ, PROFITS AND PROGRESS THROUGH LEAST-COST PLANNING 1 (1989).

17. See, e.g., Bangor Hydro-Electric Co. v. Board of Envtl. Protection, 595 A.2d 438 (Me. 1991) (upholding denial of certification of hydroelectric project for failure to show that it would not interfere with fishing, recreation, and fish habitat).

18. The annual U.S. energy bill could be reduced by between 27 and 120 billion dollars through the implementation of energy conservation measures. MosKovrz, supra note 16.

19. One dollar spent on conservation can produce up to four times as many on-site jobs as a dollar invested in capacity expansion. See Cavanagh, supra note 15, at 320. Also, new power plants require billions of dollars in investments with a substantial risk of cancellation due to the failure of demand to materialize. See, e.g., In re Washington Pub. Power Supply System Sec. Litig., 720 F. Supp. 1379 (D. Ariz. 1989) (noting that series of nuclear power plants with projected costs of $\$ 23.9$ billion canceled after demand for energy failed to materialize). For the role of energy demand in this fiasco, see Benjamin $\mathrm{E}$. Walters \& David F. Sugarman, Comment, WPPSS and the Pacific Northwest: A Mere Possibility of Unravelling a Hopelessly Twisted Debt, 16 ENVTL. L. 91, 101-02 (1985). In contrast, demand-side resources adjust automatically to fluctuations in demand. Since energy users reap these resources from changing their behavior or the materials they use, any changes in the number of these users or in the intensity of usage is automatically reflected in the demand-side resources available. Cavanagh, supra note 15 , at 317.

20. See DEMAND SIDE, supra note 12 , at II-9.

21. Id. at II-5. The "split incentives" derive from the fact that often the energy user is not the energy" purchaser, as in the case of a tenant whose apartment the landlord heats. Also, in our mobile society, individuals may be reluctant to make long-term investments if they are uncertain that they will be remaining in their present location. $I d$. at II-9.

22. Utility rates are set to allow recovery of operating expenses and fixed costs. Once the rate is set, a utility company can increase its profits by exceeding projected sales of energy. MoskovITZ, supra note 16, at 3. See also Lori A. Burkhart, Revenue Erosion: Can Conservation Be Too Successful?, PUB. UTL. FORT., Dec. 21, 1989, at 41.

The Connecticut Department of Public Utility Control has explicitly recognized the effect of conservation on utility earnings: "Under existing ratemaking practices, there is a direct relationship between the volume of a utility's sales and its earnings level; all other things being equal, higher sales produce higher earnings. Since conservation programs generally reduce sales, this sales-earnings link is a disincentive to effective implementation of conservation programs." STATE OF CONN. DEP'T PUB. UTIL. CONTROL, REPORT TO THE GEN. ASSEMBLY: D.P.U.C. IMPLEMENTATION OF PUBLIC ACT 91-248, Doc. No. 91-07-20, at ii (Dec. 24, 1991) [hereinafter CDPUC REPORT] (emphasis removed).

23. Interview with Nancy Pitblado, Planning Analyst Supervisor, State of Connecticut Office of Policy and Management, in Hartford, Conn. (March 17, 1992) [hereinafter Pitblado Interview]; see also 
they may fear loss of esteem in an industry that has always been defined by sales. ${ }^{24}$ Despite the attractiveness of utility conservation, therefore, it is unlikely to be pursued voluntarily.

Prior to the advent of the CPP, policies in favor of conservation were enforced primarily by environmental activists intervening in utility rate cases and claiming that the utility's investment in conservation was insufficient. The issue of the appropriate level of utility conservation was resolved through adversarial procedures, with the public utility commission acting as judge. ${ }^{25}$ This method of enforcing conservation policies was unsatisfactory. Effort and resources which could have been devoted to solving C\&LM problems were instead consumed in litigation. In addition, resolving C\&LM disputes diverted the regulatory commissions' attention away from the other important issues traditionally considered in utility rate proceedings. ${ }^{26}$ In his book Dynamos and Virgins, ${ }^{27}$ David Roe chronicled one of the first of these cases, involving the Environmental Defense Fund and the Pacific Gas and Electric Company. Near the end of the book, a frustrated Roe asks whether a PG\&E official could "see any shortcut ... to the five years of litigious struggle. ... Would it have been possible to cooperate?"28

In 1987, the litigants in a rate case in Connecticut found an answer to Roe's question. In response to an order issued by the Connecticut Department of Public Utility Control (CDPUC), ${ }^{29}$ utility principals, CDPUC staff, and

Application of CL\&P to Increase its Rates and Revenues, No. 85-10-22, 1986 Conn. PUC LEXIS 116, 192 (Conn. D.P.U.C. 1986) ("CL\&P witnesses stated that they cannot guarantee the amount of demand which is under their control.").

24. This is particularly true because utility management has been dominated by engineers, rather than economists. Their focus has been on building, rather than on finding optimal economic solutions. Interview with Wilson Gonzalez, Lead Planning Analyst, State of Connecticut Office of Policy and Management, Energy Division, in Hartford, Conn. (March 17, 1992) [hereinafter Gonzalez Interview].

25. See, e.g., Re United Iluminating Co., No. 83-03-01, 55 P.U.R.4th 252, 271 (Conn. D.P.U.C. 1983) ("As noted by intervenors .... [s]everal recent public acts indicate a continued strong legislative commitment to conservation... . Unfortunately, the company continues to believe conservation is a threat rather than an opportunity."); Barasch v. Pennsylvania Pub. Util. Comm'n, 521 A.2d 482, 484 (Pa. Commw. Ct. 1987) (intervenors in hearing consider question of conservation as alternative to construction of nuclear power plant); Bangor Hydro-Electric Co. v. Public Util. Comm'n, 589 A.2d 38 (Me. 1991) (intervenors successfully obtain denial of certification of hydro-electric plant due to failure of company to consider conservation); Armond Cohen \& Michael W. Townsley, Perspectives on Collaboration As Replacement for Confrontation, PUB. UTIL. FORT., Mar. 1, 1990, at 10 ("[I]n mid-1987 . . . the traditional environmental and consumer advocates contended that a massive building program wasn't justified until the conservation resource had been more fully developed. This battle was joined in nearly every rate case and power plant siting decision in New England, as it had been for several years.").

26. Gonzalez Interview, supra note 24. For a discussion of the benefits of the CPP over litigation in rate cases, see infra text accompanying notes 58-67.

27. DAVID ROE, DYNAMOS AND VIRGINS (1984).

28. Id. at 200.

29. $R e$ Conn. Light and Power Co., No. 87-07-01, 90 P.U.R.4th 148 (Conn. D.P.U.C. 1988). This case began with the typical rate case intervention scenario. CL\&P asked CDPUC to reduce the amount it was required to spend on conservation investment. The Conservation Law Foundation intervened, and introduced evidence that "[t]he cost per kilowatt of a massive conservation project was estimated at or less than six cents per kilowatt-hour, compared with eight to 9.5 cents for new plants." William B. Ellis, The Collaborative Process in Utility Resource Planning, PUB. UTIL. FORT., June 22, 1989, at 9-10. In response, the Commission increased the CL\&P conservation budget by $\$ 7.9$ million, and requested the parties to work 
representatives from a major environmental group created the CPP, in which the contentious C\&LM issues that had been raised in the rate case were resolved through consensus-based negotiation. The group's agreements were then transmitted to CDPUC for approval. ${ }^{30}$ The feelings of the parties about this first use of the CPP are a sharp contrast to Roe's assessment of the PG\&E rate case. ${ }^{31}$ The negotiating parties quickly resolved approximately $80 \%$ of the issues that had seemed unresolvable in the adversarial setting. ${ }^{32}$ By May 1990 , all proposed utility conservation programs were in operation, and the utility estimated that approximately $\$ 50$ million in capacity expenses had been avoided. ${ }^{33}$

\section{THE CURRENT STRUCTURE OF THE CPP}

The purpose of the CPP is to provide a consensual alternative to rate case litigation for the development of C\&LM proposals. ${ }^{34}$ It is conducted in specially formed negotiation groups, or "collaboratives." There are three general types of CPP participants: utilities, nonutility parties (NUP's), and representatives of the regulatory commission staff. ${ }^{35}$ NUP's are parties that have an acknowledged interest in the matter, and they are often drawn from the intervenors in an ongoing rate case. ${ }^{36}$ In their study of collaboratives nationwide, undertaken for the United States Department of Energy, Raab and

together to determine how the money should be spent. See 90 P.U.R.4th at 217 ("The Company shall develop an electric conservation work plan ... in consultation with Department staff and interested parties and intervenors to this proceeding.").

30. See Letter from members of CL\&P collaborative to Robert J. Murphy, Executive Secretary, Connecticut Department of Public Utility Control (May 25, 1988), in Northeast Utilities Collaborative Notebook, on file at the Connecticut Office of Policy Management, Hartford, Conn. [hereinafter N.U. Notebook].

31. See, e.g., id. ("Consensus has been reached on a major portion of the programs that have been discussed. ... [W]e hope to continue this cooperative approach to address difficult and complex C\&LM issues ...."). CDPUC was similarly pleased with the experiment. See, e.g., Letter from Robert J. Murphy, Executive Secretary, Connecticut Department of Public Utility Control, to Walter F. Torrance, Jr., Senior Vice President and General Counsel, Northeast Utilities (June 22, 1988), in N.U. Notebook, supra note 30 ("The Authority indicated its pleasure with the cooperation and dedication of all the participants .... The planning process has brought together a group with diverse interests to produce programs . . . The Authority encourages the committee to continue its work to resolve the outstanding issues").

32. NANCY HIRSH, BUILDING A BRIGHTER FUTURE: STATE EXPERIENCES IN LEAST-COST ELECTRICAL PLANNING 22-23 (1990).

33. Id. at 23.

34. See Comments on the Collaborative Procedures by the Nonutility Parties Participating in the UI and CL\&P Collaboratives and by the United Illuminating Company 1 (Oct. 9, 1992), [hereinafter NUP Comments], in Notice of Written Comments, State of Connecticut, Department of Public Utility Control (Oct. 9, 1992), and Responsive Comments [hereinafter Notice of Comments \& Comments] (on file with author).

35. See, e.g., Memorandum of Understanding for Connecticut Light \& Power Co. Collaborative at 1 (August 15, 1990) [hereinafter CL\&P Memorandum] (on file with author); Southem Connecticut Gas Company Conservation Collaborative Procedural Guidelines at 1 [hereinafter SCGC Guidelines] (on file with author).

36. JONATHAN RAAB \& MARTIN SCHWEITZER, PUBLIC INVOLVEMENT IN INTEGRATED RESOURCE PLANNING: A STUdy of DEMAND-SIDE MANAGEMENT Collaboratives 9 (1992). 
Schweitzer found five different types of NUP's represented: "consumer/public advocates ... ; environmental/conservation advocates; large industrial electricity users; state regulatory advocacy staff; and state energy offices.",37 Commission representatives can give guidance on policy, but nothing that they say is binding on later commission actions regarding CPP results. ${ }^{38}$

The CPP operates with three tiers of authority. The regulatory commission has the final authority to approve or reject the collaborative results. Within the collaborative itself, there is an executive committee composed of persons of authority from each of the participating groups. ${ }^{39}$ Beneath this a working group, composed of mid-level managers and technical staff, works on the mechanics of the programs, and blends the suggestions and technical information from the different parties. ${ }^{40}$

A unique feature of the CPP is that the utilities fund technical supervisors for the NUP's. ${ }^{41}$ Most NUP's would find it impossible to obtain necessary research in any other way, and would thus be forced either to accept the technical data provided by the utility or to return to litigation. ${ }^{42}$ In addition, utilities often supply the NUP's with proprietary information, which the NUP's agree not to disclose or use in a later adversarial proceeding if the collaborative fails. ${ }^{43}$

The CPP allows parties to plan and develop conservation programs in a comprehensive and integrated manner, rather than simply resolving problems

37. Id. at 13. The most frequently represented NUP's were those representing environmental concerns, followed by those representing consumer concerns. $I d$. at 14 .

38. See, e.g., Robert J. Murphy, Executive Secretary, Connecticut Department of Public Utility Control, Letter appointing Mark Quinlan, Connecticut Department of Public Utility Control Assistant Rate Specialist, to represent CDPUC in the first collaborative, April 11, 1988 in N.U. Notebook, supra note 30. Regarding Mr. Quinlan's role, the letter states:

Although Mr. Quinlan may occasionally make program suggestions, his primary purpose will be to observe the process and facilitate consensus development. D.P.U.C. staff involvement does not imply that actions taken at the meetings, statements in the minutes of the meetings or programs recommended by the group are approved by the D.P.U.C.

39. See Agreement for the Collaborative Development of Demand-Side Management Programs for United Illuminating Co. [hereinafter U.I. Agreement] (on file with author); CL\&P Memorandum, supra note 35, at 1; see also HIRSH, supra note 32, at 23.

40. HIRSH, supra note 32, at 23; U.I. Agreement, supra note 39, at 1. CL\&P includes additional subgroups as needed. CL\&P Memorandum, supra note 35, at 1-2. As a backdrop to the structure of authority it was established in the initial collaborative that "[a]lthough the purpose of this cooperative effort is to reach consensus ... [ [the utility] retains full control and final authority over all decisions." C\&LM Working Group Meeting Minutes 1 (March 11, 1988) [hereinafter March 11 Minutes], in N.U. Notebook, supra note 30 .

41. March 11 Minutes, supra note 40, at 1; see also CL\&P Memorandum, supra note 35, at 3; U.I. Agreement, supra note 39, at 2 .

42. See Cohen \& Townsley, supra note 25 , at 11 ; Ellis, supra note 29 , at 10-11. The utilities, of course, also derive a benefit from the provision of funding: if they do not provide it, the other parties will not participate. Interview with Allan Johanson, Assistant Director of Energy Unit, State of Connecticut Office of Policy and Management, in Hartford, Conn. (March 17, 1992).

43. See, e.g., CL\&P Memorandum, supra note 35, at 3 ("II]n order to promote the spirit of cooperation and compromise intended by this agreement, it is understond and agreed that the collaborative effort ... is in the nature of settlement discussions and that any intemal communication ... [or] documents, reports or other materials prepared by the parties or their experts . . . shall be neither admissible nor discoverable ...."). 
related to an isolated rate case. ${ }^{44}$ Meetings of either executive group or working group participants are scheduled as necessary. ${ }^{45}$ At these meetings, C\&LM proposals are suggested or modified, data from the technical experts is introduced and discussed, and policy issues are raised.

All decisions within the collaboratives are made by consensus. ${ }^{46}$ Different methods are used to accomplish this result, including referring unresolved issues to a smaller subgroup ${ }^{47}$ or hiring specially trained consensus facilitators. ${ }^{48}$ The ultimate purpose of the CPP is to create a stipulated agreement on C\&LM proposals. CPP agreements provide a mechanism for creating this stipulation and describe the extent to which it will be considered binding on CPP parties. ${ }^{49}$ This stipulation then forms the basis for the C\&LM proposals that the utility submits to the regulatory commission. ${ }^{50}$ Once a consensus is reached on outstanding issues, rather than disbanding, the collaborative participants turn their attention to new matters.

The basic design of the CPP has been adopted to resolve conflicts between utilities and intervenors around the country. ${ }^{51}$ The CPP often seems responsible for substantial increases in utility conservation budgets and in consumer participation in conservation programs. ${ }^{52}$ Nationwide, annual

44. See, e.g., March 11 Minutes, supra note 40, at 1 ("The outside interested parties see an ongoing process where they are not only part of the planning but also monitor implementation as well as evaluate and make suggestions for modifications when necessary."); see also C\&LM Working Group Meeting Minutes 3 (March 25, 1988), in N.U. Notebook, supra note 30 (outlining list of long-term issues which would have to be addressed by the Oversight Committee after the collaborative filing).

45. There is a wide variety in the frequency of CPP group meetings. The Connecticut Office of Policy and Management recommends tentatively scheduling meetings twice a month, see Letter from Susan Shimelman, Under Secretary, Connecticut Office of Policy and Management, to Robert J. Murphy, Executive Secretary, Connecticut Department of Public Utility Control app. 3 (Oct. 9, 1992) [hereinafter Shimelman Letter], in Notice of Comments \& Comments, supra note 34, while Yankeegas believes that meetings once a month might be too frequent, see Consolidated Gas Utility Comments on Collaborative Process Guidelines [hereinafter Consolidated Gas Utility Comments], in Notice of Comments \& Comments, supra note 34 , at 3 .

46. See March 11 Minutes, supra note 40 , at 1; U.I. Agreement, supra note 39, at 1; SCGC Guidelines, supra note 35 , at 4 . The SCGC Guidelines note that programs may be filed without unanimous agreement as long as opposing viewpoints are represented. $I d$.

47. See March 11 Minutes, supra note 40 , at 2 .

48. See, e.g., Letter from E.F. Taylor, Jr., Director, Conservation and Load Management Department, Northeast Utilities, to members of CL\&P collaborative (February 17, 1988), in N.U. Notebook, supra note 30 (announcing hiring of Terry Barnett of Conflict Management, Inc.).

49. See, e.g., SCGC Guidelines, supra note 35 , at 3-4.

50. See, e.g., Shimelman Letter, supra note 45, at app. 3-4.

51. The process has been used in California, Ohio, Massachusetts, New Hampshire, Rhode Island, New York, Maryland, Wisconsin, and elsewhere. RAAB \& SCHWEITZER, supra note 36, at 4 (1992). But see Re Benefits to Ratepayers and Utilities from Implementation of Conservation Programs that Will Reduce Electric Use, No. 89-15, 103 P.U.R.4th 97 (N.Y.P.S.C. 1989) (declining to require utility to enter into collaborative process).

52. Since it began using the collaborative process, for example, Boston Edison (BE) experienced the following: in 1987, 18,484 BE customers participated in C\&LM, compared to 108,691 in 1990. In 1987, BE spent $\$ 5.2$ million on conservation, and produced $10.4 \mathrm{GWH}$ in energy savings. In 1990 , it spent $\$ 29.5$ million and produced $127.6 \mathrm{GWH}$ in energy savings, plus $97.87 \mathrm{MWH}$ in capacity savings. Bernice K. McIntyre \& Bernard W. Reznicek, Collaborative Approaches to Conservation, PUB. UTL. FoRT., March 1,1992 , at $16,19$. 
C\&LM investment by utilities using some version of the CPP rose from $\$ 247$ million to $\$ 648$ million during the time that the CPP was used. ${ }^{53}$

\section{AN Evaluation OF THE CPP}

\section{A. The Benefits of the CPP Over Rate Case Litigation}

From the perspective of the participants, the CPP is a success. ${ }^{54}$ The satisfaction of the participants may be due to the fact that C\&LM disputes are particularly suited to resolution through ADR. The Negotiated Rulemaking Act of $1990^{55}$ provides a list of the characteristics that make disputes appropriate for resolution through negotiation. Among these characteristics are a limited number of significantly affected interests, adequate representatives for these interests, and parties that are willing to negotiate in good faith. ${ }^{56} \mathrm{C} \& \mathrm{LM}$ disputes almost always possess all three of these characteristics. The parties to C\&LM disputes tend to be utilities and large, well-organized public interest groups. These parties are limited in number and easily identified, and their own institutional structures produce adequate representatives. The dissatisfaction that these parties have experienced with rate case litigation makes them willing to negotiate in good faith. ${ }^{57}$

A comparison of rate case litigation with the CPP points out several reasons why the CPP might be preferable for resolving C\&LM-related disputes. In rate cases, parties take extreme positions, withhold from opponents information that might be fruitfully shared, and present the impression that their opponents' views are without merit, thereby foreclosing any chance to learn from them. The need to present a fissureless adversarial facade causes parties to place equal weight on all of their arguments, giving neither the other side nor the commission an indication of what is centrally important to them, or on what issues they would be willing to compromise. ${ }^{58}$

In rate cases, the parties are kept away from each other, in part from the fear that they will disclose forensically significant information. Contact is made through lawyers, who do not have the authority or knowledge to adjust

53. RAAB \& SCHWEITZER, supra note 36 , at 46 . It is impossible to say what increases would have occurred had utilities and NUP's pursued litigation instead. Also, whether these numbers represent a success depends on whether the money was well spent.

54. On April 7, 1992, CDPUC held a "Technical Meeting" with several of the Connecticut CPP participants to discuss the advantages, disadvantages, and future scope of the collaboratives. See Agenda of Technical Meeting (on file with author). At this meeting, it was unanimously agreed that the collaboratives were a vast improvement over intervention in rate cases. Raab and Schweitzer found similar enthusiasm in their study of CPP participants. RAAB \& SCHWEITZER, supra note 36 , at 38 .

55. Pub. L. No. 101-648, \$ 3(a), 104 Stat. 4969, 4970-77 (codified at 5 U.S.C.A. $\$ 581-90$ (West Supp. 1992)).

56. 5 U.S.C.A. \$ 583 (West Supp. 1992).

57. See genterally, Cohen \& Townsley, supra note 25; Ellis, supra note 29.

58. Cf. Administrative Conference of the UंNITED States, Negotlated Rulemaking SOURCEBooK 2 (David M. Pritzker \& Deborah S. Dalton eds., 1990) [hereinafter SouRCEBOoK]. 
proposals flexibly. In the CPP, it is the technical staff and principals of the parties themselves who meet face-to-face, and these individuals have the resources to create optimal solutions. ${ }^{59}$

Because of the confidentiality that CPP agreements provide, problem solving is enhanced through access to all relevant information. This creates opportunities to achieve "win-win" results, where parties reach previously unconsidered outcomes which will make them all better off. ${ }^{60}$

In rate cases, each issue is aired before the commission and is potentially the subject of a binding determination applicable in other situations. This forces parties to attend to principles out of concern for precedent rather than to solve practical problems..$^{61}$ In the CPP, parties are able to exchange ideas out of the view of the commission, giving them the chance to introduce subtle improvements and persuade other parties of the soundness of their point of view. ${ }^{62}$

Since C\&LM programs tend to be prototypical or experimental, they may be inherently unsuited to adversarial factfinding procedures. ${ }^{63}$ Experimental programs benefit from early participation from all parties concerned. In the litigation context, the only way for NUP's to have input into these programs was to challenge utility proposals once they were fully formed and before the regulatory commission. By contrast, the CPP gives NUP's a chance to participate in designing conservation programs from their inception, and to influence policy before planners become intellectually or emotionally wedded to an idea. ${ }^{64}$

The CPP is also particularly suited to C\&LM problems because it enlightens the utilities and the NUP's about the objectives and constraints of their opposition. In the collaboratives, NUP's learn the realities of implementing programs in the context of a large company, ${ }^{65}$ and utility

59. HIRSH, supra note 32, at 30. Cf. 5 U.S.C.A. $\$ 581$ (note on Congressional findings) (West Supp. 1992); Philip J. Harter, Negotiating Regulations: A Cure for Malaise, 71 GEO. L.J. 1, 28 (1982).

60. Cf. Mary-Lynne Fisher \& Arnold I. Siegel, Evaluating Negotiation Behavior and Results: Can We Identify What We Say We Know?, 36 CATH. U. L. REv. 395, 423 (1987).

61. Cf. HenRY H. PERRTT, JR., U.S. Dept. OF LABOR, Use OF Negotiated RUleMaknng to DEVELOP A PROPOSED OSHA HEALTH STANDARD FOR MDA 33 (1988) reprinted in SOURCEBOOK, supra note 58, at 661 .

62. While nothing prevented the parties in ratemaking cases from meeting to discuss issues before, the fact that they were in opposing "armed camps" made this highly unlikely. Comments at Technical Meeting, see Agenda of Technical Meeting, supra note 54.

63. Telephone Interview with Peter Boucher, former Commissioner, Connecticut Department of Public Utility Control (Mar. 18, 1992) [hereinafter Boucher Interview]; see also The Forum: Question 2: Dispute Resolution, PUB. UTIL. FORT., Nov. 8, 1990, at 28, 30-31 [hereinafter Forum] (Kenneth Gordon of the Maine Public Utilities Commission also believes that an adversarial approach is not suited to resolving disputes over appropriate conservation measures since these disputes are about policy rather than facts).

64. Telephone Interview with Joel Gordes, Technical Coordinator, United Illuminating Collaborative (Mar. 18, 1992).

65. Cohen \& Townsley, supra note 25 , at 10-11. 
product planners learn from the creativity and experience of the NUP's and their consultants. ${ }^{66}$

Finally, in most collaboratives there are utility parties that seek to maximize profits and well-organized environmental groups that seek to maximize conservation. Contract theory would indicate that any settlement dictated by a third party would be less likely to satisfy the objectives of these parties than one that they arrived at themselves. ${ }^{67}$

\section{B. Criticism of the CPP: Illegitimacy, Expense, and the Need for an Organizing Statute}

Many collaboratives have resulted in a high level of participant satisfaction. Participant satisfaction, however, is not the sole criterion of the CPP's legitimacy or effectiveness. Some critics claim that, regardless of the impressive results of the CPP in individual cases, it is not legitimate for private parties to negotiate public policy ${ }^{68}$ The CPP is also criticized for its expense and its awkward relation to the traditional regulatory apparatus. These problems have resulted in the failure of a number of collaboratives, ${ }^{69}$ and in complaints that the CPP subverts utility regulation to serve the ends of the CPP participants. ${ }^{70}$

At this time there are no official procedural guidelines informing the development of the CPP. States have remained passive as collaboratives have evolved, allowing each to emerge ${ }^{71}$ and develop in its own way according to the contractual arrangements of the parties. ${ }^{72}$ Some regulatory agencies are now questioning whether the CPP really improves on traditional procedures and, if so, whether regulatory agencies or legislatures should act to correct some of its flaws and ensure its procedural integrity. ${ }^{73}$

66. Ellis, supra note 29, at 11-12; Telephone Interview with Philip Turner, Director of Market and Research Development, United Iluminating (Mar. 18, 1992) [hereinafter Turner Interview].

67. Interview with Wayne V. Estey, Senior Economist, Connecticut Department of Public Utility Control, in New Britain, Conn. (Apr. 7, 1992) [hereinafter Estey Interview].

68. See infra text accompanying notes 88-107.

69. See, e.g., In re Potomac Elec. Power Co., No. 834, 123 P.U.R.4th 313, 358 (WUTC 1991) (collaborative disbanded after participants "failed to demonstrate the ability to work together effectively,"); Washington Commission "Discourages" Collaboration With Customer Groups, INDUS. ENERGY BULL., Feb. 14, 1992, at 1 [hereinafter Washington Commission] (continuation of CPP discouraged since a litigation format would better serve the Commission in pursuing its objectives); Central Vermont PS is Fighting Plan Forcing Home Switch to Oil, Propane, ElEC. UTIL. WK, Jan. 28, 1991, at 4 (collaborative parties reverted to litigation because utility believed collaborative was extending beyond the scope of its authority).

70. See infra notes 88-94 and accompanying text.

71. The second collaborative, for example, was begun voluntarily when United Illuminating approached CDPUC for help in C\&LM planning. They were fortuitously able to use the same nonutility parties that were involved in the CL\&P collaborative. Turner Interview, supra note 66. For a discussion of the various ways that collaboratives have been initiated, see RAAB \& SCHWEITZER, supra note 36, at 9.

72. See, e.g., U.I. Agreement, supra note 39; CL\&P Memorandum, supra note 35; SCGC Guidelines, sipra note 35.

73. The April 7, 1992 Technical Meeting, for example, was convened to discuss, among other things, "[H]ow could the [collaborative] process be improved to make it more effective and increase the level of 
The problems of the CPP could best be addressed through the passage of an organizing statute that prescribed a format and increased its efficiency. This process has proven to be an effective solution to the problems of other experimental, ADR-based administrative procedures, particularly the Negotiated Rulemaking Process (Reg-Neg). In many ways, the CPP is reminiscent of Reg$\mathrm{Neg}$, which was developed in federal administrative agencies in the 1970's and 1980 's. At that time, selected agencies began to bring together representatives of the agency and of various interest groups to attempt to reach a consensus on a proposed rule before it was promulgated. ${ }^{74}$ By 1990 , Reg-Neg was in the same state that the CPP is in now: several rules had been successfully drafted using the process, ${ }^{75}$ but Reg-Neg had procedural and substantive imperfections. $^{76}$ The Administrative Conference of the United States (ACUS) attempted to provide guidance at the administrative level for conducting RegNegs, ${ }^{77}$ and individual agencies attempted in an ad hoc manner to develop regulatory negotiation procedures. ${ }^{78}$ Despite the availability of these administrative-level procedures, the use of Reg-Neg was uneven and unsatisfactory, largely because there was no unified body of procedural guidelines, and because agencies questioned the process's legitimacy. ${ }^{79}$ The Negotiated Rulemaking Act of $1990^{80}$ (NRA) creates a unitary response to Reg-Neg's perceived problems while allowing for flexibility.

satisfaction of those participating? . . Are procedures and/or other formal guidelines needed to improve the process?" Agenda of Technical Meeting, supra note 54. On October 9, 1992, CDPUC published a Notice of Written Comments, indicating that CDPUC intended, to the extent possible, to establish uniformity in the administration of the collaboratives by adopting procedural and program guidelines. The notice asked CPP participants to submit written comments and recommendations on procedural guidelines, program guidelines, policy guidelines, policy issues appropriate for consideration by the collaboratives, and the future role of the collaboratives in relation to the department. Notice of Comments \& Comments, supra note 34.

74. SOURCEBOOK, supra note 58 , at 1 .

75. See, e.g., 54 Fed. Reg. 14,925 (1989) (NRC); 50 Fed. Reg. 35,374 (1985) (EPA); 50 Fed. Reg. 29,306 (1985) (FAA).

76. See generally SOURCEBOOK, supra note 58.

77. See, e.g., Procedures for Negotiating Proposed Regulations (Recommendation No. 85-5), 1 C.F.R. $\$$ 305.85-5 (1992); Procedures for Negotiating Proposed Regulations (Recommendation No. 82-4), I C.F.R. $\$ 305.82-4$ (1992).

78. See, e.g., EPA Regulatory Negotiation Project, 48 Fed. Reg. 7,494 (1983) (announcing creation of Regulatory Negotiation Project to test utility and value of Reg-Neg and suggest guidelines for utilizing the procedure).

79. See, e.g., 5 U.S.C.A. $\$ 581$ (West Supp. 1992) (note on Congressional findings) (federal agencies did not use Reg-Neg widely prior to passage of the NRA, in part because they were uncertain as to their authority to use the procedure); Negotiated Rulemaking Act of 1989: Hearings Before the Subcomm. on Administrative Law and Governmental Relations of the House Comm. on the Judiciary, 101st Cong., 1st Sess. 22, 24 (1989) (statement of Marshall J. Breger, Chairman, Administrative Conference of the United States) [hereinafter Breger Statement] (claiming agencies were hesitant to use Reg-Neg without authorizing statute "because they question whether they have the statutory authority to delegate the process of drafting a proposed rule to a committee. Or, they may question the implication of the Federal Advisory Committee Act for negotiated rulemaking. ... [A] statute would remove any doubt about agency authority.").

80. Pub. L. No. 101-648, \$ 3(a), 104 Stat. 4969, 4970-77 (codified at 5 U.S.C.A. \$ 581-90 (West Supp. 1992)). 
Although it is too early to fully evaluate the success of the NRA, the preliminary data appears promising. The NRA provides a formalized method for participants to gain access to the procedure, thereby alleviating many due process concerns about the informal use of Reg-Neg. ${ }^{81}$ Relying on the statute, a variety of federal agencies are now using Reg- $\mathrm{Neg}^{82}$ and some agencies have successfully used the process to develop proposed rules. ${ }^{83}$ Other agencies have used the procedures established in the NRA to determine that rules under consideration were not appropriate for Reg-Neg, and would be better developed through traditional administrative processes. ${ }^{84}$

The NRA, and the experience of federal agencies in developing it, can be instructive in designing an organizing statute for the CPP. There are significant differences between Reg-Neg and the CPP, however, which indicate that an organizing statute for the CPP should be different in many respects from the NRA. Reg-Neg negotiation groups are assembled to produce one rule, while CPP groups are long-term planning units with life spans of several years. ${ }^{85}$ Because of the diversity of factual situations and parties that the NRA must accommodate, no substantive public policy preferences are established in that statute: it is procedural only. The CPP is exclusively for the utility industry, and was developed to address disputes over utility conservation, so the organizing statute should contain a statement of the societal preference for conservation over expansion of energy production capacity. Finally, there is no analogue to the relationship between utilities and regulatory commissions in most situations in which Reg-Neg is used. These differences should be reflected in differences between the NRA and the organizing statute for the CPP.

When faced with the prospect of codifying the CPP, many CPP participants expressed fear that this would stifle the creativity and flexibility that has been responsible for the process's success. ${ }^{86}$ It is true that, in its

81. See infra text accompanying notes 116-118.

82. See, e.g., 57 Fed. Reg. 42,533 (1992) (EPA); 57 Fed. Reg. 39,661 (1992) (FCC); 57 Fed. Reg. 1,139 (1992) (Coast Guard, DOT).

83. The proposed FCA regulations for apportioning administrative expense assessments were based in large part on a Reg-Neg Committee formed pursuant to the NRA. See 57 Fed. Reg. 47,288 (1992). In addition, EPA has developed its proposed rule on the regulation of fuels and fuel additives and standards for reformulated and conventional gasoline through the NRA. See 57 Fed. Reg. 13,416 (1992).

84. See, e.g., Determination Not To Establish a Negotiated Rulemaking Committee, 57 Fed. Reg. 10,62I (1992) (FERC). In this instance, FERC considered using the NRA to develop a uniform and comprehensive proposed regulation governing ex-parte communications between persons outside the Commission and Commission officials and employees. Relying on the criteria for appropriateness for the procedure established in the NRA, FERC determined that the number of significant identifiable interests would be too large to permit them to be represented by a balanced committee of workable size.

85. The shortest collaborative studied by Raab and Schweitzer had been ongoing for six months. Others had been ongoing for over three years. RAAB \& SCHWEITZER, supra note 36, at 43.

86. This fear was voiced by many of the CPP participants with whom I spoke in the course of preparing this Note. See also Letter from Terry C. Ranger, Director, Conservation and Load Management, Northeast Utilities, to Robert J. Murphy, Executive Secretary, Connecticut Department of Public Utility Control 2 (Oct. 9, 1992) [hereinafter Ranger Letter], in Notice of Comments \& Comments, supra note 34 ("IA]n important aspect of the collaborative process . . . is its informal format. . . . CL\&P would be 
initial stages, the CPP may have benefited from a lack of regulation, since traditionally hostile parties might have been unwilling to cooperate within a statutory framework that limited their routes of escape if the experiment failed. The time for unstructured experimentation, however, has passed. Due process requires that affected interests have equal access to the CPP proceedings, and efficiency concerns require guidelines to increase the CPP's transferability to new utilities and new problems. In addition, portions of the organizing statute for the CPP could be permissive, allowing CPP participants to opt out of specific provisions.

If the statute makes these allowances for flexibility, ${ }^{87}$ continued opposition to statutory guidelines from present CPP participants deserves less consideration. Regardless of the effort that these parties expended to develop the CPP, they have no "squatter's right" in maintaining it as a private preserve of political power. An organizing statute could maintain a large part of the flexibility that CPP participants legitimately prize, while eliminating the insularity that the CPP's critics legitimately fear.

\section{Specific Criticisms of the CPP and Appropriate Legislative Responses}

\section{a. Political Legitimacy of the CPP}

Some critics claim that negotiation-based administrative procedures are per se illegitimate..$^{88}$ In order to participate in a CPP, a party must be large, powerful, and well-organized. While such parties can be counted on to represent their own interests, critics have pointed out that the CPP participants do not necessarily represent the public interest. ${ }^{89}$

Utility regulatory agencies were created to actively promote the public interest, not just the interests of the regulated community and their most well-

concerned if the Department, in an attempt to achieve some uniformity . . . diminished the usefulness of the CL\&P collaborative process."); NUP Comments, supra note 34, at 2 ("IG]uidelines [for the CPP] should . . . not bring a degree of rigidity which may make the process less effective.").

87. The NRA addresses the fear of Ioss of flexibility directly: "Nothing in this subchapter should be construed as an attempt to limit innovation and experimentation with the negotiated rulemaking process or with other innovative rulemaking procedures otherwise authorized by law." 5 U.S.C.A. $\$ 581$ (West Supp. 1992).

88. See, e.g., Wiliam Funk, When Smoke Gets in Your Eyes: Regulatory Negotiation and the Public Interest-EPA's Woodstove Standards, 18 ENVTL. L. 55, 89 (1987).

89. See, e.g., Bruce W. Radford, The Hijackers Meet the Sharp Pencil, PUB. UTIL. ForT., Oct. 1, 1991, at 4 ("It's been suggested lately that environmentalists [in the CPP] have hijacked the state public service commissions, pushing utility regulators toward resource management, and away from their traditional role, which was to oversee a regulated monopoly, keep rates down, and service up."); see also Forum, supra note 63, at 31 (Dean J. Miller of the Idaho Public Utilities Commission, discussing the use of ADR to settle utility-regulatory disputes, warns that "[c]are must be taken . . . to avoid transferring the decision-making responsibility away from public officials and into the hands of private negotiators."); Alfred E. Kahn, Environmentalists Hijack the Utility Regulators, WALL ST. J., Aug. 7, 1991, at A-10 (suggesting that public interest intervenors may have "captured" public utility commissions). 
organized adversaries. ${ }^{90}$ Traditionally they have done this through an analytically-based approach which considers policy objectives, and chooses alternatives for meeting those objectives based on a rational decision about what will most effectively advance the public good. ${ }^{91}$ The CPP substitutes for this public law solution a private law solution whose goal is arriving at a consensus among the negotiating parties. ${ }^{92}$ This means that CPP results can satisfy the participants and at the same time fail to satisfy objective determinations of the public good. ${ }^{93}$ In their study of collaboratives nationwide, in fact, Raab and Schweitzer found that the process consistently enabled some groups to satisfy their interests more than others. ${ }^{94}$

Troubling conflicts arise between the requirements of due process and the needs of the CPP as currently organized. Successful collaboratives can endure for years ${ }^{95}$ without a change in personnel, which can allow the participants to lose sight of concerns other than those of their CPP colleagues. ${ }^{96}$ In addition, the confidentiality of the CPP proceedings, and the fact that utilities fund the research efforts of the NUP's, create the risk that utilities will co-opt NUP's, or will be perceived to have done so.

Finally, both co-option and confidentiality problems aggravate-and are aggravated by - the risk of subsequent litigation. Proprietary information is shared within the collaborative to facilitate planning and negotiation. Because this information must be kept confidential, the CPP does not create a formal evidentiary record to support its results if a nonparticipant challenges them or if the commission does not approve the collaborative stipulation. ${ }^{97}$ Parties

90. See, e.g., CONN. GEN. STAT. \$ 16-2(g) (1991) ("No member of the [CDPUC] shall ... have any interest ... which is in substantial conflict with the proper discharge of his duties or employment in the public interest . . . ."); id. $\$ 16-19$ (a) (1991) (CDPUC to investigate proposed rate amendments when necessary for public interest).

91. Cf. Funk, supra note 88 , at $90-91$.

92. $C f$. id. at 92 .

93. Cf. Wald, supra note 4 , at 22 ("The parties could have good reason to want a particular result even if it made little or no sense ...."). This is an often-expressed fear in administrative law cases. See, e.g., Home Box Office, Inc. v. F.C.C., 567 F.2d 9, 53 (D.C. Cir.), cert. denied, 434 U.S. 829 (1977) (concerning rules for pay television: "[W]e are particularly concerned that the final shaping of the rules we are reviewing here may have been by compromise among the contending industry forces, rather than by exercise of the independent discretion in the public interest the Communications Act vests in individual commissioners."); Scenic Hudson Preservation Conference v. FPC, 354 F.2d 608, 620 (2d Cir. 1965), cert. denied, 384 U.S. 941 (1966) (administrative agency's role as representative of the public interest "does not permit it to act as an umpire blandly calling balls and strikes for adversaries appearing before it; the right of the public must receive active and affirmative protection at the hands of the Commission.").

94. RAAB \& SCHWEITZER, supra note 36 , at 40.

95. See id. at 43.

96. Some CPP participants may be recognizing this fact. In response to a request from CDPUC for suggestions on procedural guidelines for the CPP, Susan Shimelman of the Connecticut Office of Policy and Management responded that she welcomed the "Department's intention to establish uniformity in procedural and program guidelines" because the CPP "needs to be institutionalized in a manner which permits more public participation at critical points." Shimelman Letter, supra note 45.

97. In Re Connecticut Light and Power Co., No. 90-12-03, 124 P.U.R.4th 532 (Conn. D.P.U.C. 1991), for example, the parties to a CPP presented a consensus-based conservation budget to CDPUC. Although the Commission "appreciate[d] the work the collaborative group ha[d] done," it decided that "in light of the present capacity situation and pressures to hold down rates," id. at 569 , it would reduce the conservation 
who feel that their interests were not represented in the CPP are more likely to engage in post-collaborative litigation to challenge the results. ${ }^{98}$ If the commission is biased in favor of the results of the CPP, nonparticipants, who have already been excluded from the planning process, will also have a more difficult time influencing the agency by traditional means. ${ }^{99}$ On the other hand, if the commission grants no presumption in favor of the CPP results, participation in the CPP may be stifled. Most parties do not have the personnel to develop records for rate cases concurrently with participation in collaboratives, and since orders are formulated in rate cases, parties fearing litigation may consider forsaking the CPP. Similarly, collaborative participants-who regularly concede less important points on the promise that their most important concerns will be addressed ${ }^{100}$-will not be willing to compromise if they fear that the points that they have won may be rejected later by the commission. ${ }^{101}$

There is a significant danger, therefore, that the utilities and the participating NUP's will be able to achieve mutually acceptable results which, if adopted by the commission, could unfairly affect the rights of nonparticipants. This can happen in a number of ways. The conservation measures adopted by the CPP usually must be justified as cost-effective. ${ }^{102}$ Cost-effectiveness, however, can be measured by the effect on the program participants' energy bills, on all utility customers' energy bills, or on total

budget for the 1991-1992 year from $\$ 63$ million to $\$ 55$ million. CDPUC REPORT, supra note 22 , at 19 . Because no record had been developed in the rate hearing to support the proposed level of conservation, there was very little that the CPP participants could do in response. Gonzalez Interview, supra note 24. The WUTC in Washington, D.C. recently discouraged the use of the CPP, in part because it felt that the process presented it with conclusions without sufficiently showing how those conclusions were reached. The WUTC "expressed the need to better document the collaborative process-and its results-to ensure a public record." Washington Commission, supra note 69. Grant Tanner, a lawyer for the Washington Industrial Committee For Fair Utility Rates, which had participated in this CPP, also felt that the lack of a record was a weakness in the process, stating that "[t]he litigation format does allow you to build a record so you can go to court if you are dissatisfied with the result." Id ; see also RAAB \& SCHWEITER, supra note 36, at 32 33 (discussing CPP filings to which regulatory commissions have ordered changes).

98. Raab and Schweitzer noted that nearly all of the approvals of CPP results thus far have come only after contested hearings in which parties who were not part of the CPP, or who were part of the CPP but did not accept its results, litigated their concerns before the regulatory commission. RAAB \& SCHWEITZER, supra note 36 , at 31-32.

99. Cf. Mark Seidenfeld, A Civic Republican Justification for the Bureaucratic State, 105 HARV. L. REV. 1511, 1558 n.235 (1992) (noting similar problems with Reg-Neg). Prior to the passage of the NRA, Judge Wald of the District of Columbia Circuit was wary of granting a presumption in favor of negotiated rules, pointing out that there were no mechanisms in place to ensure sufficient interest representation to warrant such a presumption. Wald, supra note 4 , at 20-22.

100. Boucher Interview, supra note 63; see also SOURCEBOOK, supra note 58, at 6 .

101. Boucher Interview, supra note 63; $c f$. Harter, supra note 59, at 112 (listing among the fears about participating in Reg-Neg that the agency might reject proposed agreement and make fundamental changes).

102. See, e.g., Re Connecticut Light and Power Co., No. 90-12-03, 124 P.U.R.4th 532, 568-71 (Conn. D.P.U.C. 1991); CDPUC REPORT, supra note 22, at iii. 
societal resources. ${ }^{103}$ A measure can be "cost effective," therefore, while increasing the utility bills of particular segments of the population. ${ }^{104}$

The choice of conservation program designs can also have disparate impact on different groups. Utility investment programs for the residential sector that are limited to loans or partial grants, for example, may exclude participation by indigent, senior, or rental households. ${ }^{105}$ As a result of such investments, however, these households may still pay higher utility bills. ${ }^{106}$ Building design professionals, energy service companies, and others may also be particularly affected by the specific conservation measures chosen. ${ }^{107}$

The CPP should not be considered illegitimate per se simply because it uses negotiation between interested private parties to arrive at solutions to public problems. The traditional model of objective and analytical policy formation by administrative agencies has no preeminent claim to legitimacy. ${ }^{108}$ We allow private parties in civil suits with broad social ramifications to negotiate settlements, which are then judicially approved. ${ }^{109}$ In addition, we require utilities to carry out public policies not integrally related to their central mandate of providing utility services. ${ }^{110}$ Surely these same utilities, who best know their own capabilities, should also participate in shaping these policies. ${ }^{111}$

103. Shimelman Letter, supra note 45 , at 2.

104. See Kahn, supra note 89. ("[W] hen commissions begin to impose on [utilities] responsibilities and large costs at the expense of nonparticipants in the conservation programs, it is time to ask whether that is compatible with their historic mandate.... I suggest we add to the conventional wisdom about the 'capture' of regulatory agencies by the companies they are supposed to regulate, a recognition of the possibility of capture by public interest intervenors ....").

105. Cavanagh, supra note 15 , at $n .124$.

106. See, e.g., Re Connecticut Light and Power Co., No. 90-12-03, 124 P.U.R.4th 532, 570 (Conn. D.P.U.C. 1991) ("The cost of C\&LM programs must be paid by all customers, which results in higher rates.").

107. RAAB \& SCHWEITZER, supra note 36 , at 16.

108. The constitutionality of American administrative agencies, both federal and state, has been, and continues to be, questioned on a number of grounds. See STEPHEN G. BREYER \& RICHARD B. STEWART, ADMINISTRATIVE LAW AND RegUlatory Policy 33-139 (3rd ed. 1992).

109. Harter, supra note 59, at 36-38; see, e.g., Liddell v. Missouri, 731 F.2d 1294 (8th Cir.), cert. denied, 469 U.S. 816 (1984) (approving consent agreement reached by African-American parents, city, and state).

110. Estey Interview, supra note 67. See, e.g., CONN. GEN. STAT. \$ 16-262c (1992) (no electric or gas company may terminate or refuse to reinstate residential electric or gas service in hardship cases between November and April); id. $\$ 16-19 \mathrm{dd}$ (1990) (moratorium on changing rates of agricultural customer from residential to commercial rates).

111. This is particularly true because many of these policy measures are undertaken for reasons other than efficiency. See, e.g., Re Connecticut Light and Power Co., No. 88-05-25, 100 P.U.R.4th 452, 472 (Conn. D.P.U.C. 1988) ("A program targeted to a particularly needy group may argue for its adoption over another which has greater conservation or load management impact."). Legislators that make these kinds of choices are immune from their impacts. A utility, however, faces the risk that the expenditure will be disallowed as imprudent. See, e.g., Application of CL\&P to Increase its Rates and Revenues, No. 85-10-22, 1986 Conn PUC LEXIS 116, *192 (Conn. D.P.U.C. 1986) (while the CDPUC told the company to "initiate economic conservation and load management measures and not rely on pre-approval," it warned also that "[T]he Authority is specifically concemed about conservation programs which cannot assure that conservation will actually occur."). Utilities interested in protecting their shareholders, therefore, will be more risk-averse in carrying out state policies than legislators might prefer. Estey Interview, supra note 67. The CPP addresses this problem by providing a limited preapproval of conservation expenditures. See 
As currently implemented, however, the CPP does not have safeguards adequate for protecting the public good. The organizing statute which I suggest in this Note addresses this concern in several ways. First. it creates a formal method for parties to gain access to CPP negotiations. Second, it clarifies the procedural rights and obligations of the participants within a collaborative. Finally, the statute contains an expression of legislative preference for utility conservation over expanded production capacity. This would ensure that, although the CPP results were achieved by interested private parties, they took objectively-determined public policy goals into account.

The lack of a formal method of gaining access to a collaborative is currently one of the CPP's most troubling shortcomings. ${ }^{112}$ There are two types of parties to a collaborative: parties mandatory to all collaboratives, ${ }^{113}$ and parties who must be included because the particular proceeding affects their interests. ${ }^{114}$ The statute could provide a list of mandatory parties and define the roles they should play.

The current practice of determining nonmandatory CPP participants by choosing the intervenors in an ongoing rate case ${ }^{115}$ is not appropriate, because interests may be affected that do not have the resources to intervene. In rate cases, the commission could be expected to represent these interests. The more passive role of the commission in the CPP requires that greater care be taken to include disenfranchised parties.

The NRA provides a two-step process for party selection. First, the agency formally identifies the parties that will be affected by the matter. ${ }^{116}$ Second, the intent to conduct a negotiated rulemaking is published in the Federal Register and appropriate trade papers. ${ }^{117}$ Additional parties can join the negotiations after showing that they are significantly affected by the action and that their interests will not be adequately represented unless they join. ${ }^{118}$

A similar procedure should be prescribed for the CPP. The regulatory commission could be charged with the responsibility of identifying the likely

CDPUC REPORT, sIpra note 22 , at 12 ("The Collaborative process . . . involves a certain degree of preapproval.").

112. The Connecticut Business and Industry Association, for example, contends that its interests are not currently being represented in certain collaboratives in Connecticut, but has no formal method for gaining access to the negotiations. Pitblado Interview, supra note 23. See also HIRSH, supra note 32, at 30 ("Industrial and commercial interests are noticeably missing from the collaborative processes in Connecticut. All interested parties should have an opportunity to participate in the process.").

113. The most important mandatory party to each CPP is the regulatory commission itself. The other mandatory parties will differ from state to state, and should be selected from the various state agencies whose mandate is relevant to the issue of C\&LM. The NRA requires the presence of a representative of the lead agency when Reg-Neg is used. 5 U.S.C.A. $\$$ 585(b) (West Supp. 1992).

114. See Wayne V. Estey, Connecticut Dep't Pub. Util. Control, Draft Collaborative Process Guidelines, [hereinafter Draft Guidelines] (on file with author).

115. RAAB \& SCHWEITZER, supra note 36 , at 9.

116. 5. U.S.C.A. $\$ 583$ (a) (West Supp. 1992). This task can be delegated to a specially appointed convener. Id. $\$ 583(\mathrm{~b})$.

117. Id. $\$ 584(\mathrm{a})$.

118. Id. $\$ 584(\mathrm{~b})$. 
participants. After appropriate publication, interested parties that are not located by the commission should be given a chance to show that they deserve a place at the negotiating table. Because collaboratives are ongoing, potential parties should be able to make application to join at any time during the course of a collaborative. To avoid disrupting negotiations, however, they should not be granted voting status unless they join some reasonable period of time prior to the finalizing of a stipulated agreement. Parties that join a collaborative too late should be granted voting status once the stipulated agreement has been completed and the collaborative has moved on to new matters.

An organizing statute that provides a clear and open method for parties to gain access to the procedure would also be justified in creating a presumption in favor of the CPP results in any subsequent commission proceedings. ${ }^{119}$ Parties challenging the CPP results should bear the burden of demonstrating to the commission that their interests were not adequately represented, and that they had made a good-faith attempt to participate in the collaborative and were unable to. ${ }^{120}$ Similarly, if the commission proposed to alter the consensual agreement, it should be required to explain in writing its reasons for overcoming the presumption in favor of the collaborative results.

As a corollary to this presumption, the organizing statute for the CPP could provide a mechanism for developing a cognizable record in the collaboratives while maintaining the confidentiality that is essential to C\&LM development. For example, the Southern Connecticut Gas Company Conservation Collaborative Procedural Guidelines require that minutes be kept of every collaborative meeting. These minutes are circulated to each of the participants for approval, and then filed with CDPUC. ${ }^{121}$ The statute could

119. The mechanism of creating a presumption in favor of CPP results was suggested by Commissioner Boucher. Boucher Interview, supra note 63.

120. Philip Harter suggests that rules developed through Reg-Neg should be reviewed by judges under a permissive standard which would sustain a negotiated rule "to the extent that it is within the agency's jurisdiction and actually reflects a consensus among the interested parties." See Harter, supra note 59, at 102-03. Parties challenging the rules would have to demonstrate that their interests had not been taken into account. Judges would evaluate these parties' assertions in a manner similar to that currently used to evaluate motions to intervene or challenges to the certification of class actions. If a judge determined that the challenger's interests had not been represented, Harter would further require the challenger to demonstrate that extraordinary circumstances excused its failure to raise its concerns in response to the Federal Register notice announcing the formation of the negotiating group. Id. at 104-05.

Judge Wald of the D.C. Circuit objected to Harter's suggestions because she was concerned that RegNeg procedures did not provide sufficient guarantees of adequate representation. Wald, supra note 4 , at $18-$ 25 . If the procedural guarantees which I have suggested in my proposed organizing statute were in place, see infra at app., some of Judge Wald's concems might be addressed. In addition, unlike the short-term Reg-Neg committees with which Judge Wald was familiar, collaboratives are ongoing. If a CPP group's results are granted a presumption of validity, an unsuccessful challenger of the CPP results could petition to join the collaborative at that time, an option not available to an unsuccessful challenger of a negotiated rule. The worst result that the nonparticipant would face, therefore, is that the utility rate would not reflect its concerns until the next stipulated agreement. Finally, since Reg-Neg is used for rules on a broad variety of topics, there is a chance that affected parties will not have participated simply because they were unaware that the negotiations were taking place. The CPP is only for the utility industry, and potential participants are likely to know when negotiations occur.

121. Shimelman Letter, supra note 45 , at app. 3. 
adopt this method for creating a decisional record for the CPP results, making it clear that CPP participants were entitled to redact information on confidentiality grounds. These minutes could be kept confidential to the extent permitted by state and federal law, ${ }^{122}$ and could serve as a record in case the CPP results were challenged either by the commission or by an intervenor.

A statute could help ensure that a strong conservation policy was reflected in the CPP results by establishing policy goals to guide the negotiations. ${ }^{123}$ The failure to address these goals would be grounds for rejection of the CPP results, either by the commission or by the courts.

It is now left to regulatory commissions to decide whether collaboratives place the appropriate emphasis on conservation. Many interviewees remarked that the urgency with which utilities implement conservation measures is highly dependent on whether the present commissioner is a strong advocate of conservation. In areas in which they have expertise, commissioners are granted wide discretion in the rate-setting process, ${ }^{124}$ but there is no reason to allow them discretion to emphasize or de-emphasize broad state policies.

Maine has enacted a statute providing that "[w]hen the available alternatives [for meeting utility capacity requirements] are otherwise equivalent, the commission shall give preference first to conservation and demand management." 125 This statute has been interpreted as imposing on the Maine Public Utilities Commission a burden to explain, when it permits an expansion of capacity, why it has not instead implemented conservation programs. ${ }^{126}$ Imposing a similar duty on CPP participants would ensure that the results of their negotiations conform to a conservation-oriented policy and render the support of individual regulatory commissioners less necessary to the success of conservation efforts.

It seems evident that such a policy statement would influence CPP negotiations. At present, with no specific statement of the policies that should underlie their negotiations, CPP participants are confronted with a vast array of policies reflected in more general utility statutes and commission pronouncements. ${ }^{127}$ Several CPP participants have requested more specific policy

122. Most statutes requiring disclosure of public records provide for exemptions which might apply to the information that CPP parties were most concerned about keeping confidential. See, e.g., CONN. GEN. STAT. § 1-19(b) (1991) (exempting from disclosure, inter alia, trade secrets and engineering feasibility statements).

123. In addition to protecting the public interest, this would aid negotiators. An initial, clear enunciation of goals has been identified as essential to the success of the CPP. HIRSH, supra note 32, at 3.

124. See, e.g., Darnell v. Edwards, 244 U.S. 564, 569 (1917) ("[I]n a question of rate-making there is a strong presumption in favor of the conclusions reached by an experienced administrative body after a full hearing.").

125. ME. REV. STAT. ANN. tit. 35-A, § 3191 (West 1991).

126. See Bangor Hydro-Electric Co. v. Public Util. Comm'n, 589 A.2d 38, $41-43$ (Me. Sup. Ct. 1991).

127. See NUP Comments, supra note 34, at 3-4 (giving "partial" list of 17 potential sources of policy guidance for CPP negotiations). 
guidance. ${ }^{128}$ The statute could provide this guidance with a strong statement of preference for conservation over capacity expansion.

\section{b. Efficiency of the CPP}

In addition to addressing the procedural and policy concerns discussed above, the organizing statute could make the CPP more efficient. Collaboratives consume substantial resources. ${ }^{129}$ Preparation for litigation occurs in separate offices, whereas negotiation requires multiple face-to-face meetings, which generate travel, lodging, and professional and clerical support expenses. ${ }^{130}$

A statute could streamline the CPP by providing a standard format for new collaboratives. At present, collaboratives begin in an ad hoc manner, each in its own way. ${ }^{131}$ This gives maximum flexibility, but each collaborative must re-invent the wheel. ${ }^{132}$ Flexibility can be combined with formality if the statute is permissive, ${ }^{133}$ establishing a series of default rules while allowing the parties freedom to opt out of specific provisions.

The statute could also provide a mechanism for identifying appropriate matters for the CPP. ${ }^{134}$ The NRA accomplishes this by providing a list of issue characteristics indicating appropriateness for Reg-Neg, which the convener consults before going forward with the process. ${ }^{135}$ The organizing statute for the CPP should adopt this procedure. In addition, the statute should require the commission to state, before convening a collaborative, that it

128. See Shimelman Letter, supra note 45; Ranger Letter, supra note 86; Consolidated Gas Utility Comments, supra note 45.

129. See, e.g., RAAB \& SCHWEITZER, supra note 36 , at $43-45$.

130. PERRITT, supra note 61 , at 33 .

131. For a comprehensive review of the various ways that collaboratives are initiated, see RAAB \& SCHWEITZER, supra note 36 , at 9-10.

132. The Connecticut Office of Policy and Management, a participant in all Connecticut collaboratives, claims that establishing procedural guidelines has consumed substantial amounts of time at the beginning of new collaboratives. Shimelman Letter, supra note 45. Cf. Breger Statement, supra note 79, at 25 ("Variations in procedure each time ... an agency [uses] negotiated rulemaking can be confusing to agency officials and to the public. In addition, the practice of 'reinventing the wheel' is not likely to make use of the best information available on utilizing reg-neg procedures.").

133. In this more "practical" area, the statute should be permissive. In addressing the earlier concerns, such as establishing policy directives and allowing for party participation, the statute should be mandatory. $C f$. Breger Statement, supra note 79, at 24 (arguing that NRA should include a core of procedural elements to protect and inform the public, along with fiexible practical measures).

134. Raab and Schweitzer feel that determining beforehand the appropriateness of issues is one of the most important ways to reduce the costs of the CPP. RAAB \& SCHWEITZER, supra note 36 , at 44 . When parties are truly far apart on core issues, attempts to negotiate can simply highlight differences and cause animosity. On the other hand, even if no ultimate consensus is reached, attempting the collaborative process can define the issues and separate those that can be decided collaboratively from those that cannot. HIRSH, supra note 32 , at 4 .

135. See 5 U.S.C.A. $\S 583$ (West Supp. 1992). This facet of the statute is already being used to great effect by various federal agencies. See, e.g., 57 Fed. Reg. 10,621 (1992). 
intends to use the CPP agreement as the basis for the approved conservation budget, to the extent permitted by its statutory duties. ${ }^{136}$

A statute could fix the definitions of terms, such as "consensus," 137 the interest rate for capital, ${ }^{138}$ or "cost effectiveness," from time-consuming debate. The statute could also assign responsibility for scheduling collaboratives involving different utilities in an integrated way, allowing the utilities sufficient time to plan and implement projects effectively. ${ }^{140}$

Nearly all of the interviewees agreed upon the need for a method to keep the CPP moving. The NRA requires an agency to publish "a proposed agenda and schedule for completing the work of the committee."141 This plan should be adopted for the CPP. In addition, the commission should be empowered to issue orders imposing sanctions on the utility if it does not participate in good faith, or terminating the collaborative if the commission finds that its continuance is not in the public interest.

Increased costs burden parties unequally, and a statute could standardize the provision of funds for the less-wealthy participants. The NRA empowers the agency to pay directly for the personal expenses of committee members and reasonable costs for obtaining technical assistance, ${ }^{142}$ and also to provide technical and other support directly to the participants. ${ }^{143} \mathrm{~A}$ similar plan would work for the CPP. The technical assistance could be paid for through a fund created by payments from the utilities. The size of the payments could be fixed by the commission, and could be directly recoverable by the utilities

136. Cf. 5 U.S.C.A. $\$ 583$ (West Supp. 1992) ("An agency may establish a negotiated rulemaking committee ... [if] the agency, to the maximum extent possible consistent with the legal obligations of the agency, will use the consensus of the committee . . . as the basis for the proposed rule . . .").

137. The NRA provides that: “"consensus' means unanimous concurrence among the interests represented on a negotiated rulemaking committee established under this subchapter, unless such committee- (A) agrees to define such term to mean a general but not unanimous concurrence; or (B) agrees upon another specified definition." 5 U.S.C.A. $\$$ 582(2) (West Supp. 1992).

138. While it is generally thought that the cost of money for conservation efforts should be lower than that for capacity expansion, reflecting a lower risk and fewer externalities, the actual rates are now determined by negotiation. United Illuminating, for example, uses a standard $25 \%$ inflator to the benefit side for conservation methods and has suggested that this be institutionalized. Southern Connecticut Gas, on the other hand, uses an adder of $1.58 / \mathrm{MMBTU}$ to the cost side for capacity expansion, reflecting the costs associated with the pollution that power generation creates. CDPUC REPORT, supra note 22, at 22.

139. Currently there is no uniformity among collaboratives in the definition of cost-effectiveness. Connecticut Light and Power has suggested that the Total Resource Test be adopted as the standard test for cost effectiveness. Connecticut Light \& Power Company, Summary of Comments to Collaborative Process Guidelines (1991) in Notice of Comments \& Comments, supra note 34. Conservation proposals in the Yankeegas CPP must pass the "utility test," which means that they must reduce revenue requirements. Consolidated Gas Utility Comments, supra note 45.

140. What Cavanagh describes a "“worst of all worlds' scenario" occurs when one group of utility capacity planners are planning for expansion based on current demand forecasts while a separate group is planning and implementing conservation measures that will drastically lower that demand. Cavanagh, supra note 15 , at 327 . Careful scheduling of collaboratives could help to avoid this.

141. 5 U.S.C.A. $\$ 584($ a)(5) (West Supp. 1992).

142. Id. $\S 588(\mathrm{c})$.

143. Id. $\$ 585(\mathrm{c})$. 
as standard expenses. Potential CPP participants should be able to gain access to the funds after showing that they did not have adequate financial resources to participate in the CPP, and that their participation was necessary to protect the public interest. ${ }^{144}$

This plan would equalize the relative influence of the utilities and the NUP's by ending NUP dependence on utility funding, and would also reduce the danger of co-option of the NUP's by the utilities that provide for their employment. In addition, it would spread the cost of financing the NUP's among the members of the public that they served, thereby allocating those costs most appropriately, and providing an impetus for the public to scrutinize the NUP's' performance.

Finally, it should be remembered that it is not cost alone that is relevant to determining the value of the CPP, but rather, the relation of costs to improvements in regulatory products. Even if a statute could not entirely equalize the costs of the CPP and litigation, some increase in costs may be justified if the products of the CPP are proportionately superior. ${ }^{145}$

\section{CONCLUSION}

The CPP has had admirable success in adapting the principles of ADR to the problem of utility C\&LM, but it does not provide adequately for participation by all interested parties. In addition, it does not provide a mechanism for ensuring that the public interest-not just the interests of the participating negotiators-is taken into account. Regulatory commissions should not continue to condone the use of the CPP unless these problems are addressed.

The most effective way to address these problems would be through the passage of an organizing statute that established a fair method for gaining access to the process, outlined the participants' procedural rights and

144. This arrangement would fall within the scope of the procedures outlined for state utility regulatory procedures in the Public Utilities Regulatory Policy Act of 1978, 16 U.S.C. \$\$ 2601-2645 (1989) (PURPA). This act was passed by Congress to encourage energy conservation and to provide equitable rates for electric consumers. See Lori A. Burkhart, Intervenor Funding in Utility Proceedings, PUB. UTIL. FORT., June 7, 1990, at 37, 37. Under PURPA, intervenors in state utility regulatory proceedings must be able to recover reasonable expenses if they substantially contribute to the result in the proceeding. 16 U.S.C. $\$ 2632$ (a) (1989). States may follow procedures different from those outlined in this section if they provide "an altemative means for providing adequate compensation to persons (1) who have, or represent, an interest (A) which would not otherwise be adequately represented in the proceeding, and (B) representation of which is necessary for a fair determination in the proceeding, and (2) who are, or represent an interest which is, unable to effectively participate or intervene in the proceeding because such persons cannot afford to pay reasonable attorneys' fees, expert witness fees, and other reasonable costs . ..."16 U.S.C. \$2632(b) (1989). As signatories to the stipulated agreement, participants presumptively affect the result of the proceeding considering that filing. Providing funding to these participants, therefore, could qualify as an "alternative means" contemplated by PURPA.

145. Many of the CPP participants interviewed by Raab and Schweitzer, in fact, felt that the question of cost was irrelevant, given the consensus that the CPP produced superior regulatory products. RAAB \& SCHWEITZER, supra note 36 , at 45. 
responsibilities, and stipulated policy goals that would limit the scope of the private negotiations. In addition to addressing concerns about the CPP's legitimacy, this statute could include measures to increase the CPP's efficiency.

The states that have chosen to endorse the CPP, and the parties that have been involved in its development, should now complete the task by providing the CPP with procedural integrity. If they can do so they will answer the needs of the CPP and, more importantly, the needs of the policy of energy conservation that gave it birth.

\section{APPENDIX: PROPOSED ORGANIZING STATUTE FOR THE CPP}

An act to facilitate the use of the collaborative planning process by regulated utilities: ${ }^{146}$

\section{SECTION 1: Findings}

The Legislature finds that it is in the best interests of the State to ensure that its regulated utilities pursue a long-range plan to increase, to the greatest extent reasonably possible, implementation of energy conservation measures. The Legislature further finds that:

(a) utility conservation and load management budgets and programs (C\&LM) are often established in adversarial ratemaking procedures that may discourage the affected parties from meeting and communicating with each other, and may cause parties with different interests to assume conflicting and antagonistic positions and to engage in expensive and time-consuming litigation;

(b) planning C\&LM in adversarial rate cases deprives the affected parties and the public of the benefits of face-to-face negotiations and cooperation in developing and reaching agreement. It also deprives them of the benefits of shared information, knowledge, expertise, and technical abilities possessed by the affected parties;

(c) the Collaborative Planning Process (CPP), in which interested parties participate in the development of C\&LM, can provide significant advantages over adversarial rate cases;

(d) the CPP can increase the acceptability and improve the substance of C\&LM, making it less likely that the affected parties will resist implementation of C\&LM measures or challenge such measures in court.

146. This proposed act was modeled on the following sources: The Negotiated Rulemaking Act of 1990, 104 Stat. 4969, 4970-77; ME. STAT. ANN. tit. 35-A \$ 3191 (1991); Notice of Comments \& Comments, supra note 34; CL\&P Memorandum, supra note 35; Draft Guidelines, supra note 114; SCGC Guidelines, supra note 35; U.I. Agreement, supra note 39; comments of Nancy Pitblado, Planning Analyst, Connecticut Office of Policy and Management; comments of Wayne V. Estey, Senior Economist, Connecticut Department of Public Utility Control; comments of Douglas L. Boulivar, Visiting Lecturer, Trinity College, Hartford, Conn.; I bear full responsibility, however, for several individual provisions of the statute, and for the composite product. 
SECTION 2: Purpose

The purpose of this statute is to establish a framework for the conduct of the CPP, and to encourage the Public Utilities Commission (PUC) to use the CPP when the process would enhance C\&LM development. Nothing in this statute should be construed as an attempt to limit innovation and experimentation within the CPP or with other innovative ratemaking procedures otherwise authorized by law.

SECTION 3: Definitions ${ }^{147}$

For the purposes of this statute, the term-

(a) "collaborative" means a group assembled for the purpose of developing C\&LM proposals through the use of the CPP;

(b) "consensus" means unanimous concurrence among the interests represented in a collaborative, unless such collaborative agrees upon another specified definition;

(c) "C\&LM proposal" means any proposal regarding any portion of a utility budget allocated for C\&LM, or regarding any substantive C\&LM project or design.

SECTION 4: Determination of advisability of convening a collaborative

The PUC may establish a collaborative if it determines that the use of the CPP is in the public interest. In making such a determination, the PUC shall consider whether-

(a) a utility within the jurisdiction of the PUC is currently engaged in any stage of planning, implementation, oversight, or evaluation of any portion of its budget or programs for C\&LM;

(b) there is a reasonable likelihood that a collaborative can be convened with a balanced representation of persons who-

(1) can adequately represent the interests likely to be significantly affected by the adoption of such utility's C\&LM proposals;

(2) are willing to negotiate in good faith to reach a consensus on the C\&LM proposals; and

(3) the PUC, to the maximum extent possible consistent with its legal obligations, will use the consensus of the collaborative with respect to the C\&LM proposals as the basis for the final C\&LM budget approved for such utility.

147. This Note suggests that the organizing statute should define several of the terms which are currently defined by collaboratives through negotiation. See supra notes $137-139$ and accompanying text. The actual definitions chosen for these terms, however, will depend on the needs and circumstances of the particular state and of that state's utilities. I have, therefore, included only a representative sample of the type of definitions that might be appropriate for an organizing statute for the CPP. 
SECTION 5: Publication of notice; applications for inclusion in collaborative

(a) If the PUC decides to establish a collaborative, the PUC shall publish in the state's official publication ${ }^{148}$ and, as appropriate, in trade or other specialized publications, a notice which shall include-

(1) an announcement that the PUC intends to establish a collaborative to negotiate and develop C\&LM proposals;

(2) a description of the subject and scope of the proposals to be developed, and the issues to be considered;

(3) a list of the interests which are likely to be significantly affected by the proposals;

(4) a list of the persons proposed to represent such interests and the person or persons proposed to represent the PUC;

(5) a proposed agenda and schedule for submission of proposals to the PUC for approval;

(6) a description of support for the collaborative to be provided by the PUC, including technical assistance; and

(7) an explanation of how a person may apply or nominate another person for membership in the collaborative, as provided under subsection (b).

(b) Applications for membership in collaborative

(1) Persons who will be significantly affected by the C\&LM proposals and who believe that their interests will not be adequately represented by any person specified in a notice published pursuant to subsection (a) of this section may apply for, or nominate another person for, membership in the collaborative to represent such interests. Each application or nomination shall include-

(A) a written commitment that the applicant or nominee shall actively participate in good faith in the development of the proposals under consideration; and

(B) the reasons that the persons specified in the notice published pursuant to subsection (a) of this section do not adequately represent the interests of the person submitting the application or nomination.

(c) Individuals may make application for membership according to the procedures referred to in subsection (b) of this section at the time that a collaborative is convened, or at any time during the course of an ongoing collaborative. Parties accepted for membership in a collaborative less than five months prior to the date that a stipulated agreement is scheduled to be completed by that collaborative pursuant to subsection 7(f) of this statute shall be granted voting status within the collaborative immediately following the completion of that agreement.

148. This publication should be made in whichever medium or forum the particular state places its official notices analogous to those published by the federal government in the Federal Register. 


\section{SECTION 6: Establishment of collaborative}

(a) The PUC shall limit membership in a collaborative to 15 members, unless the PUC determines that a greater number of members is necessary for the functioning of the collaborative or to achieve balanced membership.

(b) The PUC shall provide appropriate administrative support to all collaboratives, including technical assistance. The PUC may use for this purpose the services and facilities of other state agencies and public and private agencies and instrumentalities with the consent of such agencies and instrumentalities. In addition, the PUC shall provide reasonable funding for collaborative participants to contract with firms or individuals of their choice for the purpose of obtaining technical information and support as provided in subsection (c) of this section.

(c) The PUC may pay for a member's expenses incurred in contracting with private firms or individuals of their own choice to obtain technical information and support if-

(1) such member certifies a lack of adequate financial resources to obtain the technical information necessary to effectively participate in the collaborative; and

(2) the PUC determines that such member's participation in the CPP is necessary to protect the public interest.

(d) All administrative support and/or funding provided pursuant to this section shall be financed through annual payments made by each utility under the jurisdiction of the PUC. The amount of such payments shall be determined by the PUC, and any payments made by utilities under this provision shall be reimbursed to the utilities as standard expenses.

(e) The PUC is authorized to provide training in negotiation to CPP participants.

\section{SECTION 7: Conduct of collaborative}

(a) Each collaborative established pursuant to this statute shall analyze the potential for direct investment by the utility in demand-side management resources; shall design programs and/or procedures to harness that potential on a comprehensive basis; and shall design plans to facilitate the implementation of such programs and/or procedures to the full extent that they are cost-effective.

(b) When the available alternatives are otherwise equivalent, the utility shall give preference to conservation and demand management over expansion of energy-generating capacity. Any forecasted new capacity expansion identified in annual forecasts of the participating utility shall be compared to C\&LM by the collaborative, to determine whether conservation or demand-side management measures could serve as an alternative to the capacity expansion.

(c) The PUC will designate at least one representative to be present at all meetings of the collaborative. This representative can give guidance regarding PUC policy, but his or her primary purpose will be to observe the process and to facilitate consensus development. PUC Staff involvement does not imply that actions taken at the meetings, 
statements in the minutes of the meetings, or programs recommended by the group are approved by the PUC.

(d) The collaborative participants shall select by consensus a person to serve as facilitator. A person designated to represent the PUC in substantive issues may not serve as facilitator or otherwise chair the collaborative.

(e) A facilitator approved or selected by a collaborative shall-

(1) chair the meetings of the collaborative in an impartial manner;

(2) impartially assist the members of the collaborative in conducting discussions and negotiations; and

(3) manage the keeping of minutes and records of the collaborative, except that any personal notes and materials of the facilitator or of the members of a collaborative shall be exempt from disclosure under any law, state or federal, to the extent permitted by the state and federal constitutions. Within a reasonable time following each meeting of the collaborative, the facilitator shall deliver a copy of the minutes of that meeting to a designated representative of each CPP participant. Within one week of the receipt of such minutes, such designated representative may request the facilitator to redact any information that the party requesting redaction supplied, unilaterally, to the collaborative for use in its negotiations. All such requests for redaction shall be honored by the facilitator. In addition, if any designated representative disagrees with either the substance or the tone of any portion of the minutes that is not subject to that representative's redaction, that representative may supply an alternative written version of that portion, which shall be added to the minutes as an appendix. The facilitator shall not change the wording of the minutes in any other way without the unanimous consent of all parties to the collaborative. When all collaborative participants have indicated their approval of the minutes, such minutes shall be transmitted to the PUC for placement in their confidential files. Such minutes may be used by any collaborative participant for any reason only with the unanimous concurrence of all collaborative participants who have agreed not to challenge the collaborative's results.

(f) If a collaborative reaches a consensus on C\&LM proposals, it shall record that consensus in a stipulated agreement signed by all parties. The signatories to any such agreement shall not challenge any proposal contained in that agreement in any subsequent proceeding, provided that the agreement is approved, without alteration, by the PUC. The participating utility shall transmit to the PUC a filing containing the proposals adopted in the stipulated agreement. If the collaborative does not reach a consensus on C\&LM proposals, the participating utility may transmit to the PUC a filing specifying any areas in which the collaborative reached a consensus. It will remain the responsibility of the participating utility to seek PUC approval of the proposals contained in the filing, according to its statutory responsibilities. Submission of a filing to the PUC shall not terminate the collaborative.

(1) The PUC shall supply a written statement of the reasons for the rejection of any proposals adopted by unanimous consensus in a collaborative, including, where relevant, the reasons for overcoming the presumption in favor of conservation described in subsection 7(b) of this section. Before the PUC makes a determination to reject any 
proposal adopted by unanimous consensus in a collaborative, the collaborative participants shall be afforded a hearing on all relevant evidence, including any minutes of collaborative meetings on file at the PUC that have been properly approved for use by the collaborative participants pursuant to subsection (e) of this section, to contest the rejection of those proposals.

(2) All prior statutory rights of intervention into the proceedings of the PUC are preserved. Any individual challenging a proposal adopted by unanimous consensus in a collaborative, however, shall demonstrate to the PUC that their interests were not considered in the collaborative, that they were unable to participate in the collaborative, and their interests could not be fairly addressed by commencing participation in the collaborative at that time.

SECTION 8: Sanctions, Termination of collaborative

(a) The PUC may issue an order imposing sanctions on the utility for failing to cooperate in good faith with the negotiation efforts of a collaborative. The PUC may also issue an order terminating any collaborative whenever the PUC finds that the continuation of that collaborative is not in the public interest. During the time that such order is in effect, non-PUC parties to the former collaborative shall not be prevented from holding meetings. However, no representative of the PUC shall attend any such meetings, no parties to the former collaborative shall be eligible for reimbursement of funds under subsection 6(c) of this statute, and any results of negotiations conducted by the former collaborative participants shall not be subject to the requirements of Section 7 of this statute. The decision to issue an order terminating a collaborative shall be appealable to a court of general jurisdiction of this state. 
